\title{
Early Marriages Last Longer: Pre-electoral Coalitions and Government Survival in Europe
}

\begin{abstract}
While the existence of pre-electoral coalitions modifies fundamentally the bargaining environment in which potential cabinet formulas are negotiated the survival chances of cabinets which include them follow predictable, yet different patterns than those of 'regular' coalition governments. The paper combines original and existing datasets on Western and Central and Eastern European cabinets with information about pre-electoral coalitions (1944-2008), in order to estimate the impact of such alliances on government survival rates. In doing so, I employ a Cox Proportional Hazard model and a 'competing risks' research design, which distinguishes between replacement and early election hazards. The findings indicate that both Western and Post-Communist cabinets formed by pre-electoral coalitions exhibit considerably lower rates of discretionary terminations. This effect is reversed in the case of incumbent pre-electoral coalitions. Last but not least, Western European cabinets that replicate pre-electoral coalitions are significantly less likely to end through dissolution and early elections.
\end{abstract}


In recent years pre-electoral coalitions (PECs) have increasingly become a common reality in both Western advanced democracies (Golder 2005) and in their younger counterparts in Central and Eastern Europe (CEE) (Kitschelt et al 1999; Rose \& Munro 2009; Ibenskas 2011). Nevertheless, the amount of academic interest received by the phenomenon remained modest especially in what concerns the relationship between these electoral alliances and the formation and life cycle of cabinets taking office afterwards. As Müller, Bergman and Strøm (2008: 25) put it in their thorough review of coalition theory: '...the potential gains from inter-party coordination in the electoral arena have not received much attention in coalition research.'

The limited comparative research done until present on pre-electoral coalitions has focused mostly on the logic behind the formation of such alliances, either at party system level: testing the dis-proportionality and signaling hypotheses (Golder 2005), or in relation with the parties' individual and combined characteristics (Golder 2006a). Although less extensively pre-electoral coalitions were also studied as a source for governing coalition agreements (Strøm \& Müller 2000) and as mediating factor for proportional portfolio allocation (Carroll \& Cox 2007). A different direction of study was the experimental investigation of voters' reaction to such alliances (Gschwend \& Hooghe 2008; Hooghe et al. 2011). Beyond that, there are a vast number of country studies analyzing the context and political consequences of specific PECs (Andeweg 1989; Hanley 1999; Mitchell 1999; Saalfeld 2000; Allern \& Aylott 2009).

In her influential article, Sona Golder (2005: 645-646) identified three main reasons for which pre-electoral coalitions are significant for students of government politics: they affect the composition and policies of the cabinet; they can make the government formation process more transparent and thus provide a stronger policy mandate; and they are quite common in postindustrial democracies.

Beyond these revealing rationales, I argue that the existence of pre-electoral coalitions modifies fundamentally the bargaining environment in which potential cabinet formulas are negotiated and that survival chances of cabinets which include them follow predictable, yet different patterns than those of regular coalition governments. Consequently, the central research question addressed by this study asks: 'What is the impact of pre-electoral coalitions on government survival rates in Europe?' Secondary questions are: 'Does it make a difference for government durability whether the member parties of the PEC had governed together in the previous electoral cycle?' and 'Is the relationship different in for Central and Eastern European cabinets?'. In order 
to answer these questions I analyze the composition, structural attributes, institutional covariates and survival rates of 534 Western and Central and Eastern European cabinets, the oldest being formed in June 1944, while the most recent started governing in December 2008.

The introduction is followed by a review of the reasons for which PECs could influence governmental survival rates. Next, I present the main coordinates of the research design: data, methods and the logic behind the control variables employed. The third section introduces a number of descriptive statistics and visual representations on the incidence of cabinets including pre-electoral coalitions. The main analytical section includes the presentation and discussion of the findings of the 'competing risks' survival models. These are run first on the pooled sample, and then separately on the Western subsample in order to check more robustly the main effects, as the latter dataset allowed for a larger number of control variables. The conclusion synthesizes the main findings of the study and points to further possible avenues of research.

\section{WHY WOULD PRE-ELECTORAL COALITIONS MATTER FOR CABINET DURABILITY?}

The methodological advances that the government durability literature has made in the last decades (see the methods section) have been complemented by the development of more comprehensive theoretical accounts based primarily on formal models incorporating the voluntary termination assumption (Lupia \& Strøm 1995, 2008) or searching for governmental equilibriums (Laver \& Shepsle 1998). However, the vast majority ${ }^{1}$ of the empirical-centered work and all theoretical models of cabinet durability have failed to differentiate between cabinets based on pre-electoral coalitions and the rest. Then, why should such a distinction be important? Pre-electoral coalitions modify fundamentally the bargaining environment in which potential cabinet formulas are negotiated. Thinking in the terms of the bargaining model proposed by Lupia and Strøm (2008), PECs have the potential to increase the bargaining power of its members relative to outside partners or opponents, beyond the sum of the influences of their composing parties because they reduce both uncertainty (for voters and other political competitors) and transaction costs.

Pre-electoral coalitions should contribute to the reduction of uncertainty since many of them are essentially devised for signaling purposes: that member parties are able to form an effective government; that member parties wish to empower voters in choosing the coalition government; 
and to signal to the voters the identity of a potential future government (Golder 2005: 649-650). Reduced uncertainty implies that a substantial popular vote allowing the PEC to form the government provides the new cabinet with both higher legitimacy and a stronger policy mandate (Golder 2005: 645-646) than coalitions formed after the announcement of electoral results. Both elements could prevent or moderate the scale of radical negative swings in public opinion that sometimes bring down cabinets.

The first type of signaling argument is common in those systems dominated by a major party that manages to govern alone for extended periods of time (e.g. the Social Democratic Party in Sweden). When the other parties coalesce in a PEC and receive from voters the opportunity to replace the dominant party in power, a stable government lacking serious conflicts becomes a direct measure of their viability as alternatives to the 'usual' party in charge of administering the country.

The other two types of signaling could make cabinets founded on pre-electoral agreements and announcements more policy credible and better able to gather outside support, from voters to financial markets. Although exogenous to the cabinet itself, this confidence, or at least the feeling of predictability that PECs transmit, could help the executive fulfill better its mandate and resist challenges appearing later on.

Unlike coalition cabinets formed after elections, governments based exclusively on PECs can most likely draw on a number of institutional mechanisms, already developed to enforce and supervise the 'contract' enforcement between the partners. An example of such mechanisms is represented by coalition coordination boards that decide on disputed candidatures at regional or national level and are used afterwards to solve conflicts between members of the component parties arising in local and regional elected or appointed bodies, or at the level of governmental agencies.

Moreover, pre-electoral coalition governments might last longer because they cooperate much strongly in the legislative arena. One form of such cooperation is the majoritarian allocation of legislative offices among the PEC member parties. Whereas post-electoral coalition governments distribute legislative offices even to opposition parties in order to increase monitoring capacity and to limit the power abuses of the partners, PEC-based cabinets were shown to 'concentrate the distribution of offices within the coalition' (Carroll 2007: 15). As a consequence, PEC cabinets 
have greater control over legislative policies, fact which, in turn, is likely to help them survive for longer.

Another reason for which PECs could influence governmental durability has to do with the fact that in most of these cases partners negotiate and agree well in advance on the major policy dimensions which would form the backbone of the governmental program. The agreement on policies is extended in some cases even to portfolio allocation (Carroll 2007). Because of these arrangements and their early timing, the likelihood that the PEC member parties make credible commitments (Laver \& Shepsle 1990; Lupia \& Strøm 2008) is higher and consequently, potential disagreements appearing later on can be solved much easier. Additionally, studying coalitions in twenty-seven young and consolidated democracies, Carroll and Cox (2007) have illustrated that the plausible norm of fairness which is expected to govern the distribution of offices in such a situation does occur more often and more extensively than for other cabinets: '[p]re-election pacts that commit their signatories to enter government together introduce a strong Gamsonian element into portfolio allocations' (Carroll \& Cox 2007: 310).

The logic implying longer duration for cabinets only made out of pre-electoral coalitions, compared to those that lack a PEC or include additional parties, can be linked as well with the cooperation that some pre-electoral coalitions entail at all party organizational levels during the campaign. Thus, because their activists and mid-level party elites have fought elections together, there is a higher likelihood for them to develop an increased mutual understanding for the needs and priorities of their partners once in government. This understanding could further translate into less pressure from party leaders and the rank-and-file on the parties' members in cabinet to discard the others' concerns and embark in zero sum games. For all these reasons I hypothesize that:

H.1: Cabinets that replicate completely pre-electoral coalitions are less likely to terminate discretionary compared the rest.

The durability of PEC-based cabinets should be more visible with respect to early election terminations. In the case of a PEC cabinet, dissolution and early elections would mean rethinking an entire electoral strategy, and more precisely, taking decisions whether to keep the old PEC label, and whether and how to reposition oneself vis-à-vis PEC partners (Carroll 2007: 5). Such decisions might prove costly, especially because of the uncertainty regarding how former voters 
of the PEC would perceive the failure of the government, who is to blame for it and whether the PEC or the PEC component parties separately are worthy of a new mandate. For these reasons leaders of PEC cabinets are more likely to prefer non-electoral discretionary terminations, i.e. replacements instead of early elections.

H.2: Cabinets that replicate completely pre-electoral coalitions diminish the risk of government termination by early election.

This paper will also analyze the durability of cabinets including pre-electoral coalitions formed between the governing parties which had been in power during the term before the election. Such a situation is not uncommon, with many Western (e.g. The 'Purple Coalition' in the Netherlands) and some Eastern coalitions (e.g. Mikulas Dzurinda's cabinets in Slovakia) asking voters a mandate to continue their program and actually receiving it. For these incumbent PEC-based cabinets the prospects regarding their durability are rather ambivalent. On the one hand, they should enjoy all the positive advantages discussed above. On the other hand, the new cabinet could carry along a legacy of unresolved conflicts and personal frictions which had not exploded in the first mandate. Moreover, later in the term party leaders might become worried that their brand or label identities get blurred after so many years of cooperation with the other parties, and thus decide for an abrupt exit. Therefore I hypothesize that:

H.3: Incumbent PEC-based cabinets are more likely to terminate discretionary than the rest.

There are a number of reasons for which the relationship between PECs and government durability might work differently for CEE cabinets. On the one hand, the argument that PECbased governments are more stable because they receive a stronger policy mandate from voters should apply to a lesser extent in the post-communist systems. There is generally little mandate responsiveness in the region, parties being rather unable to clearly differentiate themselves ideologically or to follow policy promises made in campaigns ( Roberts 2009: 79-88).

On the other hand, CEE politics are characterized by 'hyper-accountability' (Roberts 2009: 72), i.e. incumbents are punished rather severely each time at polls. This can, in turn, increase significantly the electoral costs of being perceived responsible for the dissolution of a cabinet people have (almost) voted directly for. 
Unlike their CEE counterparts (Tavits 2008), Western European parties still enjoy relatively stable electorates (Mair et al 2004), fact which alleviates the risk of complete parliamentary extinction following governmental underperformance in PEC-based cabinets. The disastrous experiences of this sort, the AWS in Poland (2001) or PNTCD in Romania (2000) were faced with after just four years from the time when they came in power on waves of hope and enthusiastic support, are significant lessons that could have shaped strategic behavior of actors forming PECs and cabinets based on them in CEE.

Last but not least, another difference relevant for our comparison has to do with the fact that most Western European parties have developed and maintained strong programmatic linkages with voters, whereas a large number of parties in CEE rely mostly on charismatic and clientelistic appeals (Kitschelt 2011). This should matter because programmatic voters might value more policy responsiveness than cabinet stability if the conflict among the coalition partners revolves around key policy promises, whereas the reverse scenario seems more plausible in CEE.

H.4: The survival rates of PEC-based cabinets should be higher in Central and Eastern Europe.

Unlike Golder (2006b), I argue that the relationship between pre-electoral coalitions and cabinet durability should also apply to replacement governments, not only to those taking office immediately after elections. This is so because the common pledges made during the campaign and the corresponding expectations they raised from voters are unlikely to be forgotten when a reshuffle takes place or a new party is admitted in the coalition. In other words, even if the bargaining environment had changed since the election it is difficult to believe that the component parties can free themselves completely and credibly from the commitments made through the pre-electoral pact, and the constraints established by it. Moreover, limiting the analysis only to post-electoral cabinets could hide effects that might take a longer period of time to materialize.

\section{Control variables}

Despite the fact that there is 'no baseline model of government duration well accepted in the literature' (Golder 2006b: 128), there is a certain agreement on the building blocks that should not be absent from such models. These blocks relate to government structural attributes, 
legislative characteristics and attributes of the political system (Warwick 1994; Laver 2003; Strøm and Swindle 2002; Saalfeld 2008).

Government structural attributes. The controls pertaining to this category that I introduce in the pooled model are: Single party majority cabinet, Single party minority cabinet, Minority coalition, Minimum winning coalition, Caretaker and Maximum government duration. The Western European cabinets' models also account whether the analyzed government is an Ideologically Connected Cabinet and whether the Maximum bargaining power party is included or not.

As Damgaard puts it (2008: 314) 'single-party governments or minimal-winning coalitions are simply better equipped than others to avoid conflicts and survive.' On the other hand, single party majority cabinets are also more likely to use strategically the dissolution and early elections option (Strøm and Swindle 2002). A higher risk of discretionary termination was also associated with minority governments, fact generally explained by their limited capacity to generate effective policy (Strøm and Swindle 2002), inability that usually translates into heavy electoral loss. Caretaker governments should not last for too long given their provisional nature (Golder 2006b: 128). Maximum government duration is important because cabinets that are invested only shortly prior to the regular elections have generally little authority to implement significant policy changes and they are also less likely to be able to enjoy the benefits of such changes. Moreover, such cabinets appear more inclined to call early elections (Lupia \& Strøm 1995).

It has been argued that coalition cabinets formed between policy compatible parties, i.e. sharing common or similar stances on various ideological dimensions, perform better and have a higher durability (De Swaan 1973; Warwick 1994). Since pre-electoral coalitions are themselves more likely to appear between ideologically proximate parties it can be legitimately questioned whether the policy connection is not the cause of the hypothesized relationship between PECs and government survival rates. This is why I control for Ideologically Connected Cabinets. Finally, the inclusion of the Maximum bargaining power party in the cabinet was shown to increase government survival chances (Damgaard 2008: 318).

Parliamentary attributes. In the pooled model I control for Legislative Fragmentation using the Effective Number of Parliamentary Parties (ENPP). For the Western subsample it was also possible to control for Ideological Polarization, Parliamentary Preference Range and Duration of Formation Negotiations. All these variables account for the complexity of the bargaining 
environment and previous comparative work has emphasized the fact that they augment the risk of discretionary terminations (King et al 1990; Warwick 1994). A somewhat different control variable pertaining to the parliamentary attributes block is the Extremist party seat share, which is generally believed to influence negatively government survival, particularly for those minority cabinets that depend on some cooperation with the opposition (King et al 1990: 858; Warwick 1994: 63).

Political system attributes. In the pooled model I control for Bicameralism, Positive Parliamentarism, Semipresidentialism, the Constructive No-Confidence Vote, the Length of the Constitutional Inter-election Period and the Age of Democracy. Bicameralism and Semipresidentialism introduce additional veto players in the legislative game, which can potentially decrease the value of governing, and implicitly governmental stability (Druckman and Thies 2002; Schleiter \& Morgan-Jones 2009). Positive Parliamentarism, whether a vote of investiture is required or not, is believed to diminish average cabinet duration (Warwick 1994), although some scholars think that the governments that fail to be invested ought to be excluded from the analysis and that this additional obstacle to formation should actually influence positively survival chances (Golder 2006b). Another important institution which needs to be accounted for is the Constructive No-Confidence Vote, which is known to increase governmental durability. On the contrary, scholars consider that Constitutional Inter-election Periods lasting for more than the usual 4 years are associated with higher risks of early elections (Strøm and Swindle 2002). Last but not least, I control in all models for the Age of Democracy, because previous research (Schleiter \& Morgan-Jones 2009: 505) has shown that cabinets in younger democracies face increased risks of both replacement and dissolution terminations. This variable is particularly important for testing robustly whether there are substantive differences between the Western and Central Eastern European cabinets.

Two other institutional controls were added for the models analyzing Western European cabinets: PM Powers and the existence of Junior Ministers. Formally powerful Prime Ministers have usually a negative impact on government survival (Damgaard 2008: 317) not least because they can unilaterally decide in favor of dissolution. On the other hand, the existence of the institution of Junior Ministers has the potential to prevent intra-coalition conflicts from escalating, particularly when they play a watchdog function (Strøm, Müller and Smith 2010). 


\section{RESEARCH DESIGN}

\section{Case selection}

With one exception (Schleiter \& Morgan-Jones 2009), the vast literature on cabinet survival has failed to examine comparatively Western and Central Eastern European governments. In most cases, authors have limited themselves to underline descriptively the much lower duration rates of cabinets in the latter region (Somer-Topcu \& Williams 2008; Conrad \& Golder 2010; Tzelgov 2011). Although data on some covariates of government durability is still missing for CEE countries, an integrated test is nevertheless welcome, particularly given the already mentioned high occurrence of PECs in the region. My case selection includes all the ten ${ }^{2}$ post-communist countries which had joined the European Union until 2008, when the last cabinet enters in my sample. Their level of democratic consolidation and similar transitions make them more suitable candidates for such comparative analyses then other young post-communist democracies, such as those in the Western Balkans, which had suffered important disruptions throughout the 1990s and later on.

\section{Data}

Because the original goal was to have fully comparable samples for Western and CEE tests I adopted Sona Golder's (2006a: 195) definition of PEC, and coded accordingly electoral coalitions in CEE: '[a] pre-electoral coalition exists when multiple parties choose to co-ordinate their electoral strategies rather than run for office alone... party leaders may announce to the electorate that they plan to form a government together if successful at the polls or they may simply agree to run under a single name with joint lists or nomination agreements. The common link, though... is that (i) parties never compete in elections as truly independent entities and (ii) the co-ordination of party strategies is made public.'

Data about the duration and various characteristics of Western European Cabinets are taken from the Comparative Parliamentary Democracy Data Archive (CPDDA) (www.pol.umu.se/ccpdand) which has been assembled for the volume edited by Strøm, Müller and Bergman (2008). For the ten Central and Eastern European countries cabinet duration data was retrieved mainly from Conrad and Golder (2010).

The information on the cabinets from the 17 Western European countries was matched with data on pre-electoral coalitions, established in these polities in the same period, retrieved from Golder (2006a). I gathered myself the information on the pre-electoral coalitions in the post-communist 
democracies using mainly online sources such as the ParlGov database (Döring \& Manow 2011), the PARLINE database, and the 'Project on political transformation and the electoral process in post-communist Europe' (Popescu \& Hannavy 2001). Additional sources were the contributions gathered in the volume edited by Blondel and Müller-Rommel (2001) and the piece by Conrad and Golder (2010).

Additionally, I collected data on the control variables accounting for the institutional environment in which the CEE cabinets operated. All the ten CEE countries can be included in Bergman's (1993) positive parliamentarism category, due to their constitutional provisions regulating cabinet investiture votes. Moreover in four of them (Bulgaria, Hungary, Latvia and Slovenia) cabinets need an absolute majority be sworn into office (Ismayr 2010). The Effective Number of Parliamentary Parties (ENPP) for each of the CEE legislatures was taken from Gallagher and Mitchell (2008). Last but not least, I follow Robert Elgie's (1998) definition of semi-presidentialism.

\section{Methods}

The government durability literature has advanced considerably on a methodological level since the late 1980s debate between the scholars who argued the cabinet's structural attributes mattered (the so-called 'deterministic approach' - Strøm 1988) and those who believed governments end because of random critical events (i.e. 'stochastic approach' - Browne et al 1988). The synthesis between the two approaches, proposed by King and his colleagues (1990) became the new paradigm: survival analyses techniques with hazard rates as functions of, mainly, cabinet attributes variables provided for more robust and methodologically sound estimations, and since then they became the standard in the field (Laver 2003; Saalfeld 2008).

I use the Cox Proportional Hazards (PH) model (Cox, 1972), which is particularly suitable for government durability data since it does not force the researcher to make any assumption about the distribution of the hazard function. $\mathrm{PH}$ is a survival analysis regression used to assess net effects of covariates on the 'time to' a termination event, in our case, a cabinet leaving office. I also use robust standard errors clustered by country to correct for the eventual statistical assumption violations (e.g. non-independence of cases) and the particular distortion resulting from the absence of PECs in five of the Western European systems. 
As the different types of PEC-based cabinets could produce distinct effects corresponding to the kind of termination they had, I use Diermeier and Stevenson (1999) 'competing risks' design and the censoring regime associated with it. Thus, I estimate three survival analyses, the first corresponding to the general risk of discretionary cabinet termination (pooled hazards, see also Saalfeld 2008). For this model all cabinets terminated due to technical reasons (e.g. death of Prime Minister; regular elections) were treated as if the time of their failure was unknown and, more importantly, as their "«real duration» ... is at least the observed duration but quite possibly longer' (Laver 2003: 31) ${ }^{3}$. The second regression estimates the risk of replacement terminations ${ }^{4}$ by applying the above-mentioned treatment not only to all cabinets terminated due to technical reasons but also to those which ended with Parliament dissolution and early elections. Finally, the risk of early election terminations is estimated by considering unknown the failure time of all governments that ended naturally as well as those which were victims of changes in partycomposition, portfolio distribution, replacements of the Prime-Minister or reshuffles.

\section{WHEN, WHERE AND WHAT TYPE OF PEC COALITIONS FORM CABINETS?}

Overall, there are 125 pre-electoral coalitions included in the government in the analyzed period. ${ }^{5}$ In the 17 Western European countries investigated, $18.1 \%$ of all cabinets were based on such a coalition (74 out of 409). No PEC formed the government in Greece, Finland, Luxemburg, Spain and Great Britain. The corresponding proportion of PEC cabinets is almost three times higher in the 10 Central and Eastern European countries: 45.1\% (51 out of 113), all of them experiencing the situation at least once.

More than half (69) of the PEC based cabinets included in the dataset managed to govern alone, i.e. without having to distribute ministerial portfolios to other parties. As it can be seen from the plotted mean values in Figure 1 below, the vast majority of these cases (57) were registered in Western Europe.

\section{Figure 1 about here}


Last but not least, roughly two thirds (43 out of 74) of all the pre-electoral coalitions included in Western cabinets were part of the previous governing coalition, i.e. the cabinet in place before the last legislative election. This phenomenon hardly ever happens in CEE, where only five (about 10\%) of all PEC-s were made of incumbent parties.

\section{Figure 2 about here}

Figure 2 above illustrates the general increase in the number of cabinets that include PECs in the last decades (i.e. the black-colored bars). In Western Europe this upward trend applies also to the PECs that managed to govern without other partners. In contrast the average level of PEC cabinets resulting from incumbent governing coalitions seems rather constant after the small boost registered in the 1950s. With the addition of the data from CEE cabinets (the right-side panel of Figure 2) the overall increase in frequency of PEC cabinets becomes even more visible. The complete list including the number of cabinets, analyzed period and type of cabinets including pre-electoral coalitions is available in the Appendix (see table 3).

\section{TYPES OF PEC CABINETS AND THEIR SURVIVAL: A COMPETING RISKS DESIGN}

The results of the Proportional Hazard Cox estimations ${ }^{6}$ on the pooled sample are presented in Table 1 below.

\section{Table 1 about here}

The findings generally illustrate the importance of the two types of pre-electoral coalitions for cabinet survival. The goodness of fit is comparable with that of most models of government durability.

To start with the pooled hazards model, the hazard ratio for cabinets which replicate perfectly electoral alliances, indicates that they have a $30 \%{ }^{7}$ smaller rate of discretionary terminations. Conversely, pre-electoral coalitions that had governed in the previous legislative cycle exhibit a $60 \%$ higher discretionary termination risk. The latter finding cannot be completely attributed to 
the fact that coalition formulas that have survived for a longer period are simply more prone to die. This is because the 'incumbent PEC variable' includes also cabinets that have an enlarged composition i.e. other parties besides those which made up the previous governing coalition.

The second pooled hazards model ${ }^{8}$ includes the interaction term accounting for the effect of preelectoral coalitions that formed alone the cabinet in Central and Eastern Europe. Although the hazard ratio is smaller, as expected, the interaction is not statistically significant. At the same time, the age of democracy variable has a robust effect in both models.

The main effects in the replacement regression are relatively similar to those in the regression assessing the general risk of discretionary termination. The most important difference is that our indicator of PEC cabinets, despite pointing in the expected direction, failed to acquire statistical significance. This finding corroborates our expectation that the positive effect of PECs on government durability is less likely to concern replacement terminations. Holding the other variables constant, cabinets including pre-electoral coalitions that had governed already are $43 \%$ more vulnerable to end with replacements compared to the rest.

Last but not least, the results of the early election risk regression differ from those of the previous analyses mainly through the lack of statistical significance of both PEC variables. For all the three models (pooled hazards, replacements and dissolution hazards) the substantive effects of the pre-electoral coalition variables remain unaltered when country dummies are included in the model. Overall, these mixed findings emphasize once again the importance of evaluating separately the hazards associated with the different types of discretionary termination. In an alternative model $^{9}$ not shown here the interaction between CEE cabinets and the variable capturing the effect of all PEC-based cabinets (i.e. PECs that governed alone and 'PEC + others' formulas) indicated a significant reduction of early election risks by $65 \%$. However, given the mixed evidence we cannot corroborate the fourth hypothesis.

\section{Table 2 about here}

Table 2 above presents the PH Cox regression on the Western European sample, including a larger number of covariates for each of the three categories of control variables.

The pooled hazards regression illustrates that cabinets based on pre-electoral coalitions which had governed in the previous cycle have $81.5 \%$ higher chances to suffer from a discretionary 
termination. This happens despite the fact that the dummy variable capturing cabinets based exclusively on pre-electoral coalitions seems to have a mild positive effect on government durability, although not significant at conventional levels.

The main effects tell virtually the same story for the replacement regression. Thus, incumbent PEC cabinets appear twice as likely as the rest to end with changes in party composition, portfolio distribution or reshuffles. The other variable, pointing to the pre-electoral coalitions which govern alone, does not make a significant difference.

The most spectacular finding of the last regression is that for pre-electoral coalition cabinets the risk of early election termination is $42 \%$ smaller than that of other cabinets, all other things being equal. This very large positive effect is not reversed for cabinets including incumbent electoral coalitions, the corresponding variable failing to reach statistical significance. ${ }^{10}$

The substantive findings regarding PEC cabinets presented in Table 2 are not modified significantly by the introduction of country dummies. Moreover, these results also robust to the omission of cabinets from countries that never experienced a PEC-based cabinet. Similarly, rerunning the models without the observations from the earlier decades (when PECs were not too common) did not change much.

Controlling for ideologically connected cabinets or leaving out this variable does not make a difference for the effects of the PEC variables. Consequently, at least for the Western European data, we can safely conclude that the relationship between pre-electoral coalitions and government durability is not a spurious one, i.e. caused by the degree of ideological compatibility between the member parties.

\section{CONCLUSION}

This paper makes a double contribution to the literature on coalition cabinets. At a theoretical level I present a number of novel arguments for why should empirical and formal models of government durability integrate information on pre-electoral alliances. At an empirical level, the study illustrates the substantial risk-reducing effect that PECs governing alone have on discretionary terminations (i.e. pooled hazards) in both Western and Central and Eastern Europe. This positive relationship is most of time reversed for the incumbent PECs cabinets. Moreover, it 
seems that Western cabinets based exclusively on PECs have a much smaller chance to end through an early election.

For the Western European cabinets, it could be safely concluded that the relationship between pre-electoral coalitions and government durability is not a spurious one, i.e. caused by the degree of ideological compatibility between the member parties. Further studies should aim at replicating the same test for CEE governments - provided that they are able to gather reliable information about policy preferences of member parties. Nevertheless, the chances that the policy connection drives the results are extremely small, given the ideological fuzziness of the region's parties (van Biezen 2003; Enyedi and Toka 2007).

The findings presented in this study would greatly benefit from triangulation with more qualitative analyses of the mechanisms through which PECs are replicated into government coalitions (e.g. institutional adaptation of electoral coordination committees) and also of the actors' (party leaders, ministers) perceptions regarding these transformations and their impact on cabinet life. 


\title{
Appendix
}

\author{
Table 3 about here
}

${ }^{1}$ An exception to this is Sona Golder's (2006b: 126-134) section, titled 'Stability of Government Coalitions', part of the chapter 7 of her book. There, she tested the impact of pre-electoral coalitions on government duration, but did so using a much smaller sample and a rather limited model specification. Moreover, she tested the effect of preelectoral pacts only for those cabinets that formed right after elections. Her findings indicate the absence of a significant positive impact of pre-electoral coalitions on cabinet stability.

2 These are: Bulgaria, Czech Republic, Estonia, Hungary, Latvia, Lithuania, Poland, Romania, Slovakia and Slovenia.

${ }^{3}$ This follows the right-censoring idea (NB: not the censoring regime itself) of King et al (1990).

${ }^{4}$ Ideally, one would be able to further discriminate within this category, terminations that resulted in changes in party composition or changes of portfolio distribution from simple reshuffles (replacing ministers with politicians of the same parties). Most likely, the latter are of less substantive interest than the former. Unfortunately, such a differentiation was not possible with the available data.

${ }^{5}$ For Western Europe there were also 17 cabinets which included only one member of the pre-electoral coalition (e.g. the 1948 De Gasperi V cabinet which included only the PSI, although the Socialists had run in a PEC with the Communists, PCI). These cases were coded as 0.

${ }^{6}$ The results of bivariate analyses: log-rank and Kaplan-Meier tests are available on request.

${ }^{7}$ For hazard ratios smaller than 1 it makes more sense to interpret their inverse, following the formula: ' $100 \%-\mathrm{x}$ ', where ' $\mathrm{x}$ ' is the hazard ratio.

${ }^{8}$ Because the 'PEC governing alone' variable had no significant effect for the replacement and early elections models ran on the pooled sample, introducing an interaction term between it and 'CEE cabinets' would make no sense from a methodological point of view.

${ }^{9}$ The same model presented in table 1, column 2 with the only difference that 'PEC governing alone' variable was replaced by 'All PEC-based cabinets' and the interaction term was modified accordingly.

${ }^{10}$ In Sona Golder's (2006b) brief analysis of the impact of pre-electoral coalitions on government durability in Western Europe, the only statistically significant finding was that PECs actually increase dissolution hazards. The results presented here suggest that finding could have been an artifact which resulted from not controlling for the effect of incumbent PECs. 


\section{REFERENCES}

*** PARLINE database [Geneva, Switzerland: Inter-Parliamentary Union], available at: http://ipu.org/parline-e/parlinesearch.asp

Allern, E. H. and Aylott, N. (2009). Overcoming the Fear of Commitment: Preelectoral Coalitions in Norway and Sweden. Acta Politica 44(3): 259-85.

Andeweg, R.B. (1989), Institutional conservatism in the Netherlands: proposals for and resistance to change, in: Daalder, H., Irwin, G.A. (eds.), Politics in the Netherlands: How Much Change? London: Frank Cass.

Bergman, T. (1993). Formation rules and minority governments. European Journal of Political Research 23(1): 55-66.

Biezen, I. v. (2003), Political Parties in New Democracies. Party Organization in Southern and EastCentral Europe. Houndmills: Palgrave MacMillan.

Blondel, J. and Müller-Rommel, F. eds. (2001), Cabinets in Eastern Europe. Basingstoke: Palgrave.

Browne E.C., Frendreis, J.P. and Gleiber, D. (1988). Contending models of cabinet stability: a rejoinder. American Political Science Review 82 (3): 930-41.

Carroll, R. (2007). The electoral origins of governing coalitions. Doctoral dissertation submitted at the University of California, Saint Diego, available at: http://escholarship.org/uc/item/9t55h95d

Carroll, R. and Cox, G.W. (2007). The Logic of Gamson's Law: Pre-Election Coalitions and Portfolio Allocations. American Journal of Political Science 51(2): 300-313.

Conrad, C.R. and Golder, S.N. (2010), Measuring Government Duration and Stability in Central Eastern European Democracies. European Journal of Political Research 49(1): 119-150.

Cox, D.R. (1972), Regression models and life tables (with discussion). Journal of the Royal Statistical Society, Series B 34(2): 187-220.

Damgaard, E. (2008). Cabinet termination, in Strøm, K., Müller, W.C. and Bergman, T., eds. Cabinets and Coalition Bargaining: The Democratic Life Cycle in Western Europe. Oxford: Oxford University Press, pp. 301-326.

De Swaan, A. (1973). Coalition Theories and Cabinet Formations. Amsterdam: Elsevier.

Diermeier D. and Stevenson, R. (1999). Cabinet survival and competing risks. American Journal of Political Science 43(4): 1051-98.

Döring, H. and Manow, P. (2011). Parliament and government composition database (ParlGov): An infrastructure for empirical information on parties, elections and governments in modern democracies. Version 11/07 - 26 July 2011.

Druckman, X. and Thies, M. F. (2002). The Importance of Concurrence: The Impact of Bicameralism on Government Formation and Duration. American Journal of Political Science 46(4): 760-71.

Elgie, R. (1998). The classification of democratic regime types: Conceptual ambiguity and contestable assumptions. European Journal of Political Research 33(2): 219-238.

Enyedi, Zs. and Toka, G. (2007). The Only Game in Town: Party Politics in Hungary, in Webb, P. and White, S. (eds.) Party Politics in New Democracies. Oxford: Oxford University Press.

Gallagher, M. and Mitchell, P. eds. (2008). The Politics of Electoral Systems. Oxford and New York: Oxford University Press.

Golder, S.N. (2005). Pre-electoral coalitions in comparative perspective: A test of existing hypotheses. Electoral Studies 24: 643-663.

(2006a). Pre-Electoral Coalition Formation in Parliamentary Democracies. British Journal of Political Science 36(2): 193-212.

(2006b). The Logic of Pre-Electoral Coalition Formation. Columbus: Ohio State University Press. 
Gschwend, Th. and Hooghe, M. (2008). Should I Stay or Should I Go? An Experimental Study on Voter Responses to Pre-electoral Coalitions. European Journal of Political Research 47(5): 556-77.

Hanley, D. (1999). Compromise, Party Management and Fair Shares: The Case of the French UDF. Party Politics, 5(2): 171-89.

Hooghe, M. Marien, S. and Gschwend, T. (2011). Gathering Counter-Factual Evidence: An Experimental Study on Voters' Responses to Pre-Electoral Coalitions in Kittel, B., Luhan, W.J. and Morton, R.B., eds. Experimental Political Science: Principles and Practices. Basingstoke: Palgrave Macmillan, 413-440.

Ibenskas, R. (2011). Party Mergers in Established and New European Democracies: An Exploratory Study, paper prepared for ECPR Joint Sessions of Workshops, Saint Gallen.

Ismayr, W. (2010). Die politischen Systeme Osteuropas im Vergleich, in: Ismayr, W. ed., Die politischen Systeme Osteuropas., 3., aktualisierte und erweiterte Auflage. Wiesbaden: VS Verlag für Sozialwissenschaften, 9-78.

King G., Alt, J., Burns, N.R. and Laver, M. (1990). A unified model of cabinet dissolution in parliamentary democracies. American Journal of Political Science 34(3): 846-71.

Kitschelt, H., Mansfeldova, Z., Markowski R. and Toka, G. (1999). Post-Communist Party Systems: Competition, Representation and Inter-Party Cooperation. Cambridge: Cambridge University Press.

Kitschelt, H. (2011). Clientelistic Linkage Strategies. A Descriptive Exploration, paper prepared for presentation at the Workshop on Democratic Accountability Strategies, Duke University, Durham, May 18-19, 2011.

Laver, M. (2003). Government termination. Annual Review of Political Science, 6: 23-40.

Laver, M. and Shepsle, K.A. (1990). Coalitions and Cabinet Government. American Political Science Review 84(3): 873-890.

Laver, M. and Shepsle, K.A. (1998). Events, equilibria and government survival. American Journal of Political Science 42(1): 28-54.

Lupia, A. and Strøm, K. (1995). Coalition termination and the strategic timing of legislative elections. American Political Science Review 89(3): 648-65.

Lupia, A. and Strøm, K. (2008). Bargaining, Transaction Costs, and Coalition Governance, in Strøm, K., Müller, W. C. and Bergman, T., eds. Cabinets and Coalition Bargaining: The Democratic Life Cycle in Western Europe. Oxford: Oxford University Press, pp. 51-83.

Mair, P. Müller, W.C. and Plasser, F. eds. (2004). Political Parties and Electoral Change. Party Responses to Electoral Markets. London: Sage Publications.

Mitchell, P. (1999). Government Formation: A Tale of Two Coalitions, in Marsh, M. and Mitchell, M., eds. How Ireland Voted 1997. Boulder, Colo.: Westview, pp. 243-63.

Müller, W.C., Bergman, T. and Strøm, K. (2008). Coalition Theory and Cabinet Governance: An Introduction, in Strøm, K., Müller, W.C. and Bergman, T., eds. Cabinets and Coalition Bargaining: The Democratic Life Cycle in Western Europe. Oxford: Oxford University Press, pp. $1-50$.

Popescu, M. and M. Hannavy (2001). Project on political transformation and the electoral process in postcommunist Europe. Retrieved 15 April 2012 from www.essex.ac.uk/elections/

Roberts, A. (2009). The Quality of Democracy in Eastern Europe: Public Preferences and Policy Reforms. Cambridge: Cambridge University Press.

Rose, R. and Munro, N. 2009. Parties and elections in new European democracies. Colchester: ECPR Press.

Saalfeld, Th. (2000). Germany: Stable Parties, Chancellor Democracy, and the Art of Informal Settlement, in Müller, W.C. and Strøm, K. eds., Coalition Governments in Western Europe, Oxford: Oxford University Press, pp. 32-85. 
Saalfeld, Th. (2008). Institutions, Chance and Choices: The Dynamics of Cabinet Survival, in Strøm, K., Müller, W.C. and Bergman, T., eds. Cabinets and Coalition Bargaining: The Democratic Life Cycle in Western Europe. Oxford: Oxford University Press, pp. 327-368.

Schleiter, P \& Morgan-Jones, E. (2009). Constitutional Power and Competing Risks: Monarchs, Presidents, Prime Ministers, and the Termination of East and West European Cabinets. The American Political Science Review 103(3): 496-512.

Somer-Topcu, Z. and Williams, L.K. (2008). Survival of the fittest? Cabinet duration in postcommunist Europe. Comparative Politics 40(3): 313-329.

Strøm, K. (1988). Contending models of cabinet stability. The American Political Science Review 82(3): 923-30.

Strøm, K. and Müller, W.C. (2000). The keys to togetherness: coalition agreements in parliamentary democracies, in: Longley, L.D. and Hazan, R.Y. eds., The Uneasy Relationship between Parliamentary Members and Leaders. London: Frank Cass and Company Limited.

Strøm, K. and Swindle, S.M. (2002), Strategic Parliamentary Dissolution. American Political Science Review 96(3): 575-591.

Strøm, K., Müller, W.C., and Bergman, T., eds. (2008). Cabinets and Coalition Bargaining: The Democratic Life Cycle in Western Europe. Oxford: Oxford University Press.

Strøm, K., Müller W.C., and Smith, D.M. (2010). Parliamentary Control of Coalition Governments. Annual Review of Political Science 13: 517-535.

Tavits, M. (2008). On the Linkage between Electoral Volatility and Party System Instability in Central and Eastern Europe. European Journal of Political Research 47(5): 537-555.

Tzelgov, E. (2011). Communist successor parties and government survival in Central and Eastern Europe. European Journal of Political Research, Vol. 50(4): 530-58.

Warwick, P. (1994). Government Survival in Parliamentary Democracies, Cambridge, UK: Cambridge University Press. 


\section{Table 1}

Survival of pre-electoral coalitions governing alone (Pooled Model - Cox PH Regressions)

\begin{tabular}{|c|c|c|c|c|}
\hline & $\begin{array}{l}\text { General } \\
\text { Risk (I) }\end{array}$ & $\begin{array}{l}\text { General } \\
\text { Risk (II) }\end{array}$ & Replacement & Early election \\
\hline PEC governing alone & $\begin{array}{l}.708^{*} \\
(.131)\end{array}$ & $\begin{array}{l}.893 \\
(.190)\end{array}$ & $\begin{array}{l}.709 \\
(.176)\end{array}$ & $\begin{array}{l}.853 \\
(.240)\end{array}$ \\
\hline $\begin{array}{l}\text { Interaction PEC gov. alone and CEE } \\
\text { cabinet }\end{array}$ & & $\begin{array}{l}.457 \\
(.235)\end{array}$ & & \\
\hline Incumbent Pre-electoral coalition & $\begin{array}{l}1.591 * * * \\
(.270)\end{array}$ & $\begin{array}{l}1.396^{*} \\
(.311)\end{array}$ & $\begin{array}{l}1.432 * \\
(.268)\end{array}$ & $\begin{array}{l}1.674 \\
(.811)\end{array}$ \\
\hline Single Party Majority cabinet & $\begin{array}{l}.581 * * \\
(.127)\end{array}$ & $\begin{array}{l}.593 * * \\
(.132)\end{array}$ & $\begin{array}{l}.187 * * * \\
(.044)\end{array}$ & $\begin{array}{l}1.738 \\
(.715)\end{array}$ \\
\hline Single Party Minority cabinet & $\begin{array}{l}1.402 \\
(.327)\end{array}$ & $\begin{array}{l}1.408 \\
(.324)\end{array}$ & $\begin{array}{l}.931 \\
(.272)\end{array}$ & $\begin{array}{l}3.118 * * * \\
(1.313)\end{array}$ \\
\hline Minority coalition & $\begin{array}{l}1.343 \\
(.286)\end{array}$ & $\begin{array}{l}1.324 \\
(.277)\end{array}$ & $\begin{array}{l}1.174 \\
(.293)\end{array}$ & $\begin{array}{l}1.565 \\
(.934)\end{array}$ \\
\hline Minimum winning coalition & $\begin{array}{l}.637 * * * \\
(.109)\end{array}$ & $\begin{array}{l}.608 * * * \\
(.108)\end{array}$ & $\begin{array}{l}.505^{* * *} \\
(.104)\end{array}$ & $\begin{array}{l}1.077 \\
(.354)\end{array}$ \\
\hline Caretaker & $\begin{array}{l}3.626 * * * \\
(1.091)\end{array}$ & $\begin{array}{l}3.551 * * * \\
(1.059)\end{array}$ & $\begin{array}{l}1.761 * \\
(.517)\end{array}$ & $\begin{array}{l}7.648 * * * \\
(3.161)\end{array}$ \\
\hline Max. government duration (in months) & $\begin{array}{l}.979 * * * \\
(.005)\end{array}$ & $\begin{array}{l}.979 * * * \\
(.005)\end{array}$ & $\begin{array}{l}.998 \\
(.005)\end{array}$ & $\begin{array}{l}.945 * * * \\
(.008)\end{array}$ \\
\hline Legislative fragmentation & $\begin{array}{l}1.220 * * * \\
(.069)\end{array}$ & $\begin{array}{l}1.224 * * * \\
(.066)\end{array}$ & $\begin{array}{l}1.226 * * * \\
(.079)\end{array}$ & $\begin{array}{l}1.182 \\
(.187)\end{array}$ \\
\hline Bicameral parliament & $\begin{array}{l}1.260 \\
(.224)\end{array}$ & $\begin{array}{l}1.225 \\
(.215)\end{array}$ & $\begin{array}{l}1.117 \\
(.198)\end{array}$ & $\begin{array}{l}1.389 \\
(.569)\end{array}$ \\
\hline Positive parliamentarism & $\begin{array}{l}1.187 \\
(.226)\end{array}$ & $\begin{array}{l}1.235 \\
(.229)\end{array}$ & $\begin{array}{l}1.485^{*} \\
(.336)\end{array}$ & $\begin{array}{l}.936 \\
(.475)\end{array}$ \\
\hline Constructive no-confidence & $\begin{array}{l}.737 \\
(.201)\end{array}$ & $\begin{array}{l}.737 \\
(.203)\end{array}$ & $\begin{array}{l}.802 \\
(.246)\end{array}$ & $\begin{array}{l}.502 \\
(.288)\end{array}$ \\
\hline Semi-presidentialism & $\begin{array}{l}.957 \\
(.125)\end{array}$ & $\begin{array}{l}.954 \\
(.120)\end{array}$ & $\begin{array}{l}1.134 \\
(.201)\end{array}$ & $\begin{array}{l}.571 \\
(.220)\end{array}$ \\
\hline CIEP length (in years) & $\begin{array}{l}1.469 * \\
(.300)\end{array}$ & $\begin{array}{l}1.444^{*} \\
(.292)\end{array}$ & $\begin{array}{l}1.244 \\
(.365)\end{array}$ & $\begin{array}{l}2.028^{*} \\
(.813)\end{array}$ \\
\hline Age of democracy & $\begin{array}{l}.990 * * * \\
(.003)\end{array}$ & $\begin{array}{l}.989 * * * \\
(.003)\end{array}$ & $\begin{array}{l}.984 * * \\
(.004)\end{array}$ & $\begin{array}{l}.997 \\
(.008)\end{array}$ \\
\hline N Failing due to risk & 332 & 332 & 209 & 123 \\
\hline Log-likelihood & -1747.477 & -1746.282 & -1107.045 & -590.234 \\
\hline Wald $\chi^{2}$ & 1018.08 & 894.68 & 498.13 & 325.41 \\
\hline
\end{tabular}

$*$ Significance at $* \mathrm{p}<.10 ; * * \mathrm{p}<.05 ; * * * \mathrm{p}<.01$

** Cell entries are Hazard Ratios; robust, country-clustered standard errors in parentheses. 


\section{Table 2}

Pre-electoral coalitions and Government Survival in Western Europe (Cox PH Regressions)

PEC governing alone

General risk

Incumbent Pre-electoral coalition

.801

(.193)

Replacement

$1.815^{* * *}$

$(.405)$

Single Party Majority cabinet

.812

.859

(.356)

$581 *$

$(.257)$

$1.947 *$

$(.187)$

Single Party Minority cabinet

1.448

(.297)

Minority coalition

1.059

(.265)

Minimum winning coalition

$.499 * *$

(.671)

2.418

(1.417)

$.442 *$

1.655

(.193)

(.761)

1.106

$2.738 * * *$

(.137)

Caretaker

$1.924 * *$

(.507)

Ideologically connected cabinet

1.206

(.248)

Max. bargaining power party included

$.411 * * *$

(.129)

Max. government duration (in months)

$.967 * * *$

$(.008)$

Duration of formation negotiation

.999

(.002)

Legislative fragmentation

$1.134^{*}$

(.071)

Ideological polarization

$1.023 * * *$

(.007)

Parliamentary preference range

$.992 *$

(.004)

Extremist party seat share

$1.021 * * *$

(.010)

Bicameral parliament

$1.985 * * *$

(.513)

Positive parliamentarism

$2.149 * * *$

(.409)

(1.025)

1.234

(.465)

$.374 * * *$

1.260

(.421)

1.053

(.140)

.968

(.383)

$1.430 *$

(.275)

$412 *$

(.199)

1.002

(.006)

.997

$(.002)$

(.430)

$4.691 * * *$

(1.826)

.938

(.275)

$.456 * * *$

(.127)

$.916^{* * * *}$

(.011)

1.001

(.007)

1.257

1.182

(.194)

$1.038 * *$

$1.021 * *$

(.009)

.994

(.005)

$1.023^{*}$

(.018)

$.990 *$

(.006)

1.018

$(.012)$

1.066

(.018)

$5.192 * * *$

(.320)

(.508)

Constructive no-confidence

$.330 * * *$

(.135)

Semipresidentialism

1.185

(.196)

1.114*

(.062)

Junior ministers

$.596 * *$

(.150)

$2.147 * *$

(.777)

1.720

(2.173)

$3.114 * * *$

(.942)

$.021 * * *$

(1.046)

(0.14)

$1.883^{*}$

.597

(.654)

(.217)

$.804 * * *$

(.051)

$1.868 * * *$

1.580

(.122)

$.223 * * *$

(.480)

(.080)

CIEP length (in years)

.941

1.001

$.495 *$

(.241)

(.255)

(.196) 


\begin{tabular}{lccc}
\hline Age of democracy & .995 & $.990 *$ & .993 \\
& $(.003)$ & $(.006)$ & $(.008)$ \\
\hline N Failing due to risk & 255 & 142 & 113 \\
Log-likelihood & -1244.013 & -688.810 & -476.271 \\
Wald $\chi^{2}$ & 896.46 & 1696.31 & 2119.80 \\
\hline$*$ Significance at * $\mathrm{p}^{<.10 ; * * \mathrm{p}<.05 ; * * * \mathrm{p}<.01}$ \\
** Cell entries are Hazard Ratios; robust, country-clustered standard errors in parentheses.
\end{tabular}


Table 3

Governments and Pre-electoral coalitions in Europe

\begin{tabular}{|c|c|c|c|c|c|}
\hline Country & Period $^{10}$ & Cabinets & $\begin{array}{l}\text { Gov. based } \\
\text { on PEC }\end{array}$ & $\begin{array}{l}\text { PEC governs } \\
\text { alone }\end{array}$ & $\begin{array}{l}\text { PEC gov. } \\
\text { incumbent }\end{array}$ \\
\hline Austria & $1945-2000$ & 21 & 14 & 13 & 12 \\
\hline Belgium & 1946-1999 & 33 & 1 & 1 & 1 \\
\hline Denmark & $1945-2001$ & 31 & 1 & 1 & 0 \\
\hline Finland & 1948-1999 & 42 & 0 & 0 & 0 \\
\hline France & 1959-2002 & 23 & 17 & 11 & 8 \\
\hline Germany & 1949-2002 & 26 & 13 & 10 & 13 \\
\hline Great Britain & $1945-2001$ & 20 & 0 & 0 & 0 \\
\hline Greece & $1977-2000$ & 11 & 0 & 0 & 0 \\
\hline Iceland & $1946-2003$ & 25 & 1 & 0 & 0 \\
\hline Ireland & 1944-2002 & 22 & 4 & 4 & 0 \\
\hline Italy & 1946-1999 & 49 & 3 & 2 & 0 \\
\hline Luxemburg & 1954-1999 & 13 & 0 & 0 & 0 \\
\hline Netherlands & $1946-2002$ & 22 & 4 & 3 & 2 \\
\hline Norway & $1945-2000$ & 26 & 7 & 7 & 3 \\
\hline Portugal & 1976-1999 & 14 & 4 & 1 & 3 \\
\hline Spain & $1977-2000$ & 8 & 0 & 0 & 0 \\
\hline Sweden & $1945-2002$ & 26 & 5 & 4 & 1 \\
\hline Bulgaria & 1991-2009 & 9 & 3 & 2 & 0 \\
\hline Czech Rep. & 1993-2009 & 10 & 3 & 0 & 0 \\
\hline Estonia & 1992-2009 & 11 & 6 & 2 & 0 \\
\hline Hungary & 1990-2009 & 8 & 4 & 4 & 0 \\
\hline Latvia & 1993-2009 & 16 & 11 & 0 & 2 \\
\hline Lithuania & $1993-2008$ & 11 & 2 & 0 & 1 \\
\hline Poland & $1991-2011$ & 16 & 4 & 2 & 0 \\
\hline Romania & 1992-2009 & 13 & 8 & 1 & 0 \\
\hline Slovakia & $1993-2010$ & 10 & 1 & 1 & 0 \\
\hline Slovenia & 1993-2011 & 9 & 3 & 0 & 2 \\
\hline
\end{tabular}

